\author{
Ewa Trojnar \\ (Uniwersytet Jagielloński)
}

\title{
Japonia a procesy integracyjne w Azji Wschodniej
}

Obserwowane w drugiej połowie XX w. zacieśnianie relacji pomiędzy państwami Azji Wschodniej ${ }^{1}$ wskazuje na postępujące procesy integracji. Zaznaczają się one głównie na płaszczyźnie gospodarczej.

Międzynarodowa integracja gospodarcza dokonuje się głównie poprzez wewnętrzne i wzajemne dostosowywanie się struktur gospodarczych poszczególnych krajów, tworzenie się między nimi trwałych powiązań i spajanie ich $\mathrm{w}$ całość, stanowiącą w miarę jednolity organizm gospodarczy ${ }^{2}$. W teorii integracji wyróżnia się kilka form współpracy. Najprostszą formą współpracy regionalnej jest preferencyjna strefa handlu, w której obniża się taryfy celne whandlu towarami i usługami pomiędzy krajami regionu. Strefa wolnego handlu oznacza ich likwidację, ale autonomię w ustalaniu taryf zewnętrznych. Gdy dochodzi do wprowadzenia jednolitych ceł zewnętrznych, mówi się o unii celnej. Wspólny rynek to wyższa forma integracji regionalnej, oznaczająca dodatkowo zniesienie przeszkód w przepływie czynników produkcji (kapitału i siły roboczej). Zasadniczym warunkiem wspólnego rynku jest zachowanie stałości i pełna wymienialność kursów walutowych (wówczas można mówić o unii walutowej). Unia ekonomiczna wprowadza dodatkowo wspólną politykę monetarną i makroekonomiczną. Teoria integracji wyróżnia również pojęcie unii politycznej dla określenia wspólnej koordynacji zarówno polityki wewnętrznej,

${ }^{1}$ Regionem Azji Wschodniej będą określane państwa członkowie Stowarzyszenia Narodów Azji Południowo-Wschodniej (ASEAN), tj.: Brunei, Singapur, Malezja, Indonezja, Tajlandia, Filipiny, Kambodża, Wietnam, Laos i Birma, a także: Japonia, Korea Południowa i Chiny, tworzące wraz z państwami ASEAN płaszczyznę tzw. ASEAN + 3. Przyjęcie takiego miana może wynikać z zastosowania błędnego podziału geograficznego Azji, gdyż tradycyjnie za obszar Azji Wschodniej uznaje się północno-wschodnie oraz wschodnie Chiny, Półwysep Koreański i Wyspy Japońskie. Gdy obszary od Półwyspu Indyjskiego, przez Nizinę Hindustańską, Himalaje, Półwysep Indochiński, po Archipelag Malajski z Filipinami tworzą Azję Południową. Stosowanie nazwy regionu Azja Wschodnia w szerszym kontekście znajduje uzasadnienie w praktyce przyjętej przez państwa tworzące fora współpracy w opisywanym rejonie kontynentu azjatyckiego. Stosowane określenie znajduje wreszcie uzasadnienie w obserwowanym nasileniu regionalnych procesów integracyjnych w ostatnich latach, co jest przedmiotem prezentowanej pracy.

${ }^{2}$ E. J a n toń-Drozdowska, Regionalna integracja gospodarcza, PWN, Warszawa 1998, s. 7-10. 
jak i zagranicznej ${ }^{3}$. Pełna integracja powoduje unifikację gospodarek krajów i determinuje wspólną politykę na wielu płaszczyznach działalności.

Instytucjonalizacja przebiegu procesów integracyjnych w Azji Południowo-Wschodniej została zapoczątkowana powołaniem w 1967 r. przez przedstawicieli Indonezji, Malezji, Filipin, Singapuru oraz Tajlandii, Stowarzyszenia Narodów Azji Południowo-Wschodniej (Association of South East Asia Nations - ASEAN) ${ }^{4}$. W późniejszych latach członkostwo uzyskały również Brunei, Wietnam, Laos, Birma i Kambodża.

Zwiększenie wymiany handlowej i inwestycji w obrębie państw ASEAN wpłynęło na dalszy rozwój współpracy w regionie. Przyspieszono działania liberalizujące handel. W ramach Strefy Wolnego Handlu ASEAN (ASEAN Free Trade Area - AFTA), obejmującej od 1993 r., z wieloma wyjątkami, handel towarowy postępuje proces znoszenia taryf celnych ${ }^{5}$. Zajęto się promocją inwestycji poprzez utworzenie w 1998 r. Strefy Inwestycyjnej ASEAN (ASEAN Investment Area - AIA).

Przyszłość państw ASEAN, podobnie jak wydarzenia z przeszłości, pozostaje zmienną ewolucji zależności pomiędzy krajami regionu, gdy ich sytuacja gospodarcza jest wypadkową koniunktury w regionie. Od czasu powołania organizacji minie niedługo czterdzieści lat. Nakreślenie jej przyszłości obarczone jest jednak znacznym ryzykiem popełnienia błędu. Wśród przyczyn takiego stanu rzeczy należy wskazać wieloaspektowe zróżnicowanie krajów Azji Wschodniej oraz zwiększającą się liczbę ewentualnych członków zintegrowanego regionu. Na bazie ASEAN tworzone są nowe struktury i fora dyskusyjne. Odnosi się jednak wrażenie, że grono państw członkowskich jest zbyt zróżnicowane, aby formułować $w$ ramach organizacji plany ścisłej i instytucjonalnej integracji.

Azja Wschodnia jest regionem kontrastów. Udział państw wysoko rozwiniętych (Japonia, Singapur, Korea Południowa), bogatych w zasoby naturalne (Chiny), światowych producentów zboża (Indonezja, Tajlandia i Filipiny) świadczy o znacznym potencjale przemysłowym i rolniczym regionu. $Z$ drugiej strony, charakteryzuje go skrajne zróżnicowanie stopnia rozwoju krajów, gdzie dochód przypadający na 1 mieszkańca waha się od 1611 USD (Birma) do 29287 tys. USD (Japonia - por. tab. 1). Zróżnicowanie dotyczy również aspektu kulturowego, historycznego, a także szerokiego spektrum systemów politycznych (od demokracji po dyktatury).

${ }^{3}$ Międzynarodowe stosunki gospodarcze, red. A. Budnikowski, E. Kawecka-Wyrzykowska, PWE, Warszawa 1997.

${ }^{4}$ Geneza integracji państw Azji Południowo-Wschodniej sięga pierwszych lat po II wojnie światowej. W jej przebieg znacząco wpisał się plan rozwoju Mekongu (Mekong Development Plan). Szerzej na ten temat zob. M. P i e tra s i a k, Wielki Subregion Mekong. Pomoc Japonii w inwestycjach Subregionu Mekong, [w:] Współczesna Japonia mocarstwo na rozdrożu, red. E. Potocka, M. Pietrasiak, Wydawnictwo Uniwersytetu Łódzkiego, Łódź 2004, s. 99-103.

${ }^{5}$ E. Hali ża k, Stosunki międzynarodowe w regionie Azji i Pacyfiku, Wydawnictwo Naukowe Scholar, Warszawa 1999, s. 281-292. 
Tabela 1. Charakterystyki wybranych krajów regionu Azji i Pacyfiku (2004)

\begin{tabular}{|c|c|c|c|c|c|}
\hline \multicolumn{2}{|c|}{$\begin{array}{c}\text { Forum } \\
\text { współpracy }\end{array}$} & Kraj & $\begin{array}{l}\text { PKB w PPP (mld } \\
\text { USD) }\end{array}$ & $\begin{array}{l}\text { PKB per capita } \\
\text { w PPP (USD) }\end{array}$ & $\begin{array}{l}\text { Populacja } \\
\quad(\mathrm{mln})\end{array}$ \\
\hline & & Tajwan & 595,375 & 26240 & 22,7 \\
\hline & & Chiny (Hongkong) & 214,180 & 30970 & 6,9 \\
\hline \multirow{13}{*}{ 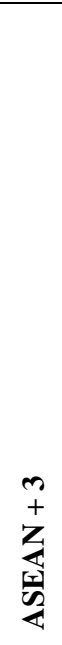 } & & Chiny & 8352,791 & 6425 & 1299,8 \\
\hline & & Japonia & 3740,792 & 29287 & 127,7 \\
\hline & & Korea Południowa & 934,232 & 19429 & 48,1 \\
\hline & \multirow{10}{*}{$\underset{2}{2}$} & Indonezja & 900,932 & 4163 & 216,4 \\
\hline & & Tajlandia & 513,489 & 7889 & 65,1 \\
\hline & & Filipiny & 386,407 & 4674 & 82,6 \\
\hline & & Malezja & 268,719 & 10551 & 25,5 \\
\hline & & Wietnam & 228,270 & 2783 & 82,0 \\
\hline & & Singapur & 115,854 & 27322 & 4,2 \\
\hline & & Laos & 11,404 & 1969 & 5,8 \\
\hline & & Kambodża & 31,800 & 2255 & 14,1 \\
\hline & & Birma & 87,510 & 1611 & 54,3 \\
\hline & & Brunei & 8,743 & 24435 & 0,358 \\
\hline & & Australia & 601,455 & 29859 & 20,1 \\
\hline & & Nowa Zelandia & 96,793 & 23826 & 4,0 \\
\hline & & Indie & 3307,176 & 3057 & 1081,5 \\
\hline \multicolumn{3}{|c|}{ RAZEM } & 13347,954 & - & 3161,2 \\
\hline
\end{tabular}

Ź ró d ł o: World Economic Outlook Database, September 2006, Międzynarodowy Fundusz Walutowy, http://www.imf.org/external/pubs/ft/weo/2006/02/data/index.aspx (stan z 21.10.2006).

Populacja Azji Wschodniej sięga 2 mld osób, co stanowi około jedną trzecią ludności świata. Chiny pozostają najbardziej zaludnionym krajem regionu, co znacznie kontrastuje z liczbą mieszkańców małych krajów, takich jak Brunei czy Singapur. Region Azji Wschodniej charakteryzuje również rozmaitość wierzeń i kultur, a w sferze organizacji państwa - nieprzestrzeganie praw człowieka w Chinach czy Birmie, które niepokoi społeczność międzynarodową. $\mathrm{Na}$ zasadzie kontrastu wyłania się demokratyczna i wysoko rozwinięta Korea Południowa czy Japonia.

Analiza osiągnięć rozwoju gospodarczego Japonii na pierwszym planie wyłania jej specyficzne, wyspiarskie położenie oraz niedobór bogactw naturalnych, co z jednej strony stanowiło przeszkodę, z drugiej sposobność nawiązania 
i utrzymywania kontaktów ze światem. Przełomowy dla omawianego tematu był okres Meiji (1868-1912) ${ }^{6}$, kiedy doszło do otwarcia Japonii na świat.

$\mathrm{W}$ pierwszej połowie XX w. Japonia prowadziła politykę ekspansjonistyczną, u podstaw której leżały również imperialne aspiracje państwa (idea „Wielkiej Japonii”, hasło „specjalnej odpowiedzialności za Azję Wschodnią”). Początkowe sukcesy w zajmowaniu nowych obszarów Azji Wschodniej: od Mandżurii ${ }^{7}$, przez Półwysep Koreański, Chiny, francuskie Indochiny (Laos, Kambodża, Wietnam), holenderskie Indie Wschodnie (Indonezja) po Filipiny, okazały się w efekcie tragiczne dla przyszłości Japonii.

W wyniku przegranej w II wojnie światowej Japonia stała się znacznie uzależniona od wpływów Stanów Zjednoczonych zarówno w aspekcie politycznym, jak i ekonomicznym. W pierwszych latach amerykańskiej okupacji wprowadzono konstytucję regulującą zasady, na których oparto nowy, demokratyczny ustrój państwa ${ }^{8}$. Równocześnie wdrożono szereg reform, które, jak się wkrótce okazało, stanowiły dobrą podstawę dalszych zmian, aż do uzyskania spektakularnych sukcesów w rozwoju ekonomicznym ${ }^{9}$.

W latach osiemdziesiątych XX w. Japonia wydawała się spełnieniem snu o azjatyckim sukcesie gospodarczym. W tej dekadzie wartość japońskiego PKB per capita była najwyższa w Azji Wschodniej (w 1989 r. - 17420 tys. USD w PPP ${ }^{10}$. Wskaźniki dochodu narodowego do dziś stawiają Japonię $\mathrm{w}$ gronie najbogatszych krajów. W 2004 r. w Azji Wschodniej produkcja przypadająca na jednego mieszkańca osiągała podobne wielkości jedynie w chińskim Hongkongu (por. tab. 1).

\footnotetext{
${ }^{6}$ Był to czas panowania cesarza Mutsuhito - okres Meiji (Oświeconych Rządów), kiedy doszło do radykalnych przeobrażeń w dotychczas feudalnej i zacofanej Japonii. Okres ten utożsamiany jest z zapoczątkowaniem zmian, które doprowadziły do powstania monarchii konstytucyjnej, jaką obecnie jest Japonia.

${ }^{7}$ Równocześnie Mandżuria miała stanowić „strefę buforową” przed zagrożeniem ze strony ZSRR i Chin.

${ }^{8}$ Konstytucja Japonii z 3 listopada 1946 r. weszła w życie w 1947 r. Konstytucja Japonii, przeł. T. Suzuki, P. Winczorek, Ossolineum, Wrocław 1990.

${ }^{9} \mathrm{~W}$ literaturze przedmiotu analizie poddaje się również szereg przemian społecznych, jakie zaszły w Japonii od II wojny światowej. Wnikliwą analizę społeczno-gospodarczych uwarunkowań wzrostu Japonii przestawia F. To mczak, Japonia. Wieś - rolnictwo - agrobiznes, Wydawnictwo Key Text, Warszawa 1997. O uwarunkowaniach wewnętrznych gospodarczej dynamiki Japonii w okresie powojennym pisze M. D o b r o c z y ń s k i, Ewolucja międzynarodowej pozycji gospodarki japońskiej, Wydawnictwo Adam Marszałek, Toruń 2004. Temat historyczno-kulturowych uwarunkowań systemu społeczno-ekonomicznego oraz ich wpływu na sukces gospodarczy Japonii podejmuje J. G r a b o w i e c k i, Japonia. Powojenna dynamika i równowaga gospodarcza, SGH, Warszawa 2000; Japan's Socio-economic Evolution. Continiuty and Change, red. S. Metzger-Court, W. Pasche, Japan Library, Folkstone 1996. Ponadto warto przywołać opracowanie S. T s u r u, Szkice o ekonomii politycznej i o gospodarce Japonii, PWE, Warszawa 1983.

${ }^{10}$ Dane za: World Economic Outlook Database...
} 
Japonia przoduje w świecie w osiaganych wielkościach obrotów handlu zagranicznego. Równocześnie kraje Azji Wschodniej pozostają od lat jej niezwykle istotnymi partnerami handlowymi, a w 2004 r. wzajemne obroty przekroczyły 15 bln jenów (ponad 140 mld USD). W 2004 r. import z państw ASEAN odpowiadał blisko 15\% (7,28 bln JPY) całkowitego importu Japonii, wynoszącego ponad 49 bilionów jenów. Eksport z Japonii do państw ASEAN sięgnął ponad 7,78 bln jenów, co stanowi około 13\% (z ponad 61 bilonów jenów) wartości japońskiego eksportu w 2004 r. Najważniejszym odbiorcą japońskiej produkcji pozostają Chiny (13\% całkowitego eksportu w 2004 r.). Wcześniej, bo w 2002 r., Chiny zajęły pozycje pierwszego importera Japonii, wyprzedzając dotychczasowych liderów - państwa Unii Europejskiej oraz Stany Zjednoczone. Kraje nowo uprzemysłowione (new industrialized economies - NIE's), tj. Korea Południowa, Singapur, Tajwan i Hongkong, odbierają blisko ćwierć japońskiego eksportu ${ }^{11}$.

Japonia jest inwestorem lokującym swoje aktywa na wszystkich kontynentach. W 2004 r. wartość inwestycji zagranicznych, których odbiorcą były kraje Azji wyniosła ponad bilion jenów i stanowiła ponad 25\% wszystkich inwesty$\mathrm{cji}^{12}$.

Japonia dostarcza wydatnej pomocy krajom słabiej rozwiniętym w postaci kredytów i wsparcia bezzwrotnego. Japońska pomoc rozwojowa (official development assistance - ODA) stanowi istotny element wkładu tego kraju na rzecz społeczności międzynarodowej, w tym wydatną pomoc dla krajów Azji Wschodniej ${ }^{13}$. Pod koniec XX w. znaczna część pomocy skierowanej do państw regionu została przekazana Indonezji, Chinom, Tajlandii oraz Filipinom na projekty własne oraz wspólne, takie, jak np. wsparcie tworzenia Subregionu Mekongu z udziałem państw indochińskich. Japońska pomoc bezpośrednia dla Azji stanowiła równocześnie największy udział regionalnych środków, przekazywanych przez japoński rząd (53,95\% z 10657 mln USD w 1995 r.). Na mocy układów i porozumień międzynarodowych region Azji należy do priorytetowych

\footnotetext{
${ }^{11}$ Źródło: opracowanie własne na podstawie danych Historical Statistics of Japan. Value of Japan Exports by Principal Country (Area) of Destination (1946-2003), Statistics Bureau \& Statistical Research and Training Institute, http://www.stat.go.jp/data/chouki/zuhyou/18-01.xls (stan z 21.03.2006).

${ }^{12}$ Japan in Figures 2006. Value of Direct Investment Abroad, Statistics Bureau \& Statistical Research and Training Institute, http://www.stat.go.jp/english/data/figures/index.htm\#l (stan z 21.03.2006).

${ }^{13} \mathrm{~W} 1954$ r. rozpoczęto konsekwentne wysiłki, mające na celu poszerzenie świadczeń w ramach ODA. Obecnie Japonia dotuje inwestycje społeczne w 150 rozwijających się krajach na wszystkich kontynentach. Warto zauważyć, że japoński rząd nie ogranicza się do świadczenia pomocy finansowej, służy również potrzebującym krajom własnym personelem, wysyłając za granicę ekspertów i ochotników oraz prowadząc szkolenia w Japonii.
} 
obszarów pomocy ${ }^{14}$. W 2004 r. pomoc Japonii skierowana do państw ASEAN wyniosła $897 \mathrm{mln}$ USD i była niższa od środków przekazanych Chinom w tym samym okresie (964 mln USD) ${ }^{15}$.

Poza niewątpliwym potencjałem gospodarczym daje się równocześnie zauważyć stale rosnące zaangażowanie polityczne oraz militarne Japonii w świecie. Wszystkie te czynniki pozwalają przypisać jej rolę ważnego mocarstwa gospodarczego w świecie, a w szczególności w Azji Wschodniej.

Kwestia miejsca Japonii w regionie Azji Wschodniej stanowi istotne zagadnienie dla wszystkich elit rządzących w tym kraju. Pozycja regionalnego lidera w płaszczyźnie gospodarczej, ale i politycznej, jest dla Japonii wyjątkowo istotna z punktu widzenia przyszłości kraju i równocześnie uzasadnia jej szersze, globalne aspiracje. Bezpieczeństwo i pokój w świecie stanowi nieodzowny warunek prosperity Japonii.

Do zwrotu w powojennej polityce zagranicznej Japonii względem państw ASEAN doszło w latach siedemdziesiątych, za rządów premiera Takeo Fuku$\mathrm{dy}^{16}$. Od 1977 r., stanowiącego cezurę w stosunkach pomiędzy partnerami, strona japońska uczestniczyła w spotkaniach na szczycie państw ASEAN, co umożliwiało aktywizację współpracy gospodarczej z regionem zgodnie $\mathrm{z}$ interesem narodowym.

Współpraca Japonii z krajami regionu została poddana weryfikacji w wyniku wybuchu kryzysu finansowego w latach 1997-1998. Wydarzenia nim powodowane wskazały na kluczowe znaczenie powiązań gospodarczych w regionie, a także na słabą zdolność zarówno organizacji regionalnych, w tym ASEAN, i potężnych gospodarczo krajów, w tym Japonii, do samodzielnego kompensowania skutków kryzysu. W celu przeciwdziałania wystąpieniu podobnych zdarzeń w przyszłości priorytetem stało się dalsze zacieśnianie więzów pomiędzy krajami regionu. Równocześnie dążono do zinstytucjonalizowania współpracy w obrębie istniejących organizacji, a także pomiędzy organizacjami i pozostałymi państwami Azji Wschodniej. Japońscy politycy, szczególnie premier Ryūtarō Hashimoto w 1997 r., ale także premier Keizō Obuchi w 1999 r. opowiadali się za zwiększeniem intensywności spotkań z przedstawicielami państw ASEAN oraz rozszerzeniem wachlarza poruszanych tematów ${ }^{17}$.

Inicjatywa powołania forum ASEAN + 3, spotkań na szczycie przedstawicieli państw członkowskich ASEAN oraz Chin, Korei Południowej i Japonii zrodziła się w 1997 r. W 1998 r. w wyniku konsultacji utworzono platformę dla

${ }^{14}$ K. S u n a g a, The Reshaping of Japan's Official Development Assistance (ODA) Charter, "Discussion Paper on Development Assistance" 2004, No. 3, s. 22.

${ }^{15}$ Geographical Distribution of Japan's Bilateral ODA in 2004, Web Japan, http://webjapan.org/stat/stats/23ODA32.htm (stan z 21.10.2006).

${ }^{16}$ E. H a 1 i ż a k, op. cit., s. 158.

${ }^{17}$ M. B r u z i k, Japonia-ASEAN w latach 1977-2003, [w:] Wspótczesna Japonia..., s. 92-96; M. P i e t r a s i a k, Wielki Subregion Mekong..., s. 105-108. 
spotkań wybitnych intelektualistów, reprezentujących 13 państw forum (East Asia Vision Group - EAVG). W 2001 r. powołano grupę badawczą, w której skład weszli przedstawiciele rządów państw forum ASEAN + 3 (East Asia Study Group - EASG). Raporty z prac obydwu grup, prezentowane odpowiednio w 2001 r. i 2002 r., dowodziły potrzeby intensyfikacji integracji nie tylko w płaszczyźnie gospodarczej, lecz także politycznej oraz w zakresie bezpieczeństwa. Rekomendacje wymienionych grup zawierały siedemnaście celów krótkoterminowych, których wypełnienie powinno nastapić do 2007 r. oraz dziewięć średnio- i długoterminowych.

Dotychczas udało się wypełnić kilka z nich. Powołano Radę Biznesu Azji Wschodniej (East Asia Business Council), zrzeszającą przedstawicieli sektora MSP oraz korporacji międzynarodowych, działających w regionie. Odniesiono sukces w budowie sieci zespołów doradczych, stanowiących zaplecze naukowo-badawcze studiów nad przebiegiem procesu integracji. Obecnie sześć zespołów prowadzi analizy $\mathrm{w}$ zakresie współpracy ekonomicznej, finansowej oraz politycznej pomiędzy państwami ASEAN + 3. Powodzeniem zakończyło się wdrożenie programu rozwoju zasobów ludzkich dzięki powołaniu jednostki zajmującej się wymianą kadr i ich rozwojem (ASEAN Plus Three Study Group on Facilitation and Exchange of People and Human Resources Development). Utworzono również Forum Azji Wschodniej (East Asia Forum) dla koordynacji współpracy w zakresie społecznym, w dziedzinie kultury i edukacji ${ }^{18}$.

$\mathrm{W}$ ramach forum ASEAN +3 funkcjonuje 48 płaszczyzn współpracy w kwestiach gospodarczych, finansowych, politycznych i bezpieczeństwa, turystyki, środowiska, energetyki i technologii teleinformatycznych.

W 2002 r. premier Japonii Junichirō Koizumi zaproponował wdrożenie Inicjatywy dla Rozwoju Azji Wschodniej (Japan's Initiative for Development in East Asia - IDEA), która spotkała się z zainteresowaniem przywódców państw ASEAN, domagających się jednocześnie sprecyzowania możliwości udziału Japonii w procesach dalszej integracji.

W 2004 r., na podstawie doświadczeń we współpracy zespołów doradców z różnych dziedzin, w Japonii powołano Radę Wspólnoty Wschodnioazjatyckiej (The Council on East Asian Community - CEAC). Zrzesza ona zespoły doradcze, naukowców, przedstawicieli świata biznesu, a także administracji publicznej, oferując szeroko rozumiane wsparcie i doradztwo na rzecz procesu tworzenia Wspólnoty poprzez współpracę z forum ASEAN $+3^{19}$.

Mimo że dialog pomiędzy państwami Azji Wschodniej dotyczy szeregu kwestii i można przytaczać wiele inicjatyw, których celem jest zacieśnianie

${ }^{18}$ Database on the Cooperation Progressing in the ASEAN Plus Three and ASEAN Plus One Cooperation Frameworks, [w:] Association of Southeast Asian Nations, http://www.aseansec.org/DATABASE_Consolidated\%20ASN+3_DB\%20as\%20of\%2017\%20Oct\%2006.pdf, s. 5-78 (stan z 12.11.2006).

${ }^{19}$ Szerzej na ten temat zob. The Council on East Asian Community, http://www.ceac.jp (stan z 17.05.2006). 
współpracy w regionie pod japońskim przewodnictwem, gruntowne ustalenia $\mathrm{z}$ trudem wychodzą poza współpracę $\mathrm{w}$ zakresie handlu (eliminowania barier i taryf) czy bieżących problemów dotyczących bezpieczeństwa, jak przeciwdziałanie terroryzmowi, a także chorobom zakaźnym.

Japonia angażuje się $\mathrm{w}$ intensyfikację integracji również poprzez bezpośrednie kontakty z przedstawicielami państw członkowskich ASEAN. Odbywają się one głównie na płaszczyźnie forum ASEAN + 1, którego pierwsze spotkanie na szczycie miało miejsce w 1997 r. Współpraca w węższym gronie umożliwia pogłębianie powiązań handlowych oraz inwestycyjnych. Służą temu dwustronne porozumienia o partnerstwie gospodarczym (economic partnership agreement EPA) negocjowane przez rząd japoński równolegle do toczących się procesów liberalizacji handlu w ramach Światowej Organizacji Handlu. Do 2006 r. podpisano takie porozumienia z Filipinami, Malezją i Tajlandią. Regulują one szerszy zakres działań niż umowy dotyczące wolnego handlu (free trade agreement - FTA $)^{20}$. Obecnie strona japońska negocjuje zawarcie podobnych porozumień z Indonezją, Wietnamem, Brunei, ASEAN jako organizacją, a także z Koreą Południowa.

W grudniu 2005 r. w Kuala Lumpur miało miejsce pierwsze spotkanie na szczycie przedstawicieli państw szeroko rozumianej Azji Wschodniej w ramach Szczytu Azji Wschodniej (East Asia Summit - EAS) ${ }^{21}$. Wśród zaproszonych uczestników znaleźli się przedstawiciele dziesięciu państw członkowskich ASEAN oraz goście reprezentujący zamożne kraje świata z wyjątkiem Stanów Zjednoczonych, a więc Japonia, Korea Południowa, Chiny (ASEAN + 3), Indie, Australia, Nowa Zelandia (być może w przyszłości forum: ASEAN $+3+3$ ). W roli obserwatora wystapiła delegacja Rosji. W końcowej deklaracji stwierdzono, że ustanowienie współpracy w ramach szczytu jako forum do rozmów strategicznych, politycznych oraz dotyczących spraw ekonomicznych leży we wspólnym interesie wszystkich państw, a jego celem jest popieranie pokoju, stabilizacji oraz dobrobytu w Azji Wschodniej ${ }^{22}$.

Analizując rolę Japonii w przebiegu integracji w regionie, warto przytoczyć możliwe scenariusze uwzględniające uwarunkowania regionalne i globalne. Czy zaangażowane $\mathrm{w}$ procesy integracji $\mathrm{w}$ Azji Wschodniej państwa powinny zmierzać do utworzenia strefy wolnego handlu (East Asian Free Trade Area EAFTA) na podstawie zawieranych obecnie bilateralnych porozumień gospodarczych? Czy należy położyć większy nacisk na wartości łączące społeczeń-

${ }^{20}$ Pierwszym porozumieniem tego typu była umowa zawarta pomiędzy rządami Japonii i Singapuru w $2002 \mathrm{r}$.

${ }^{21}$ Dokumenty źródłowe dotyczące szczytu zob.: ASEAN, http://www.aseansec.org/ 17724.htm ( $\operatorname{stan}$ z 12.11.2006 r.) oraz 11th ASEAN Summit, http://www.11thasean-summit. org.my/mainpage.php ( $\operatorname{stan}$ z 12.11.2006).

${ }^{22}$ Ibidem. 
stwa krajów regionu i budować Wspólnotę Wschodnioazjatycką (East Asian Community - EAC) w oparciu o trzy filary: gospodarczy, polityki i bezpieczeństwa oraz społeczno-kulturowy?

Współpraca gospodarcza krajów Azji Wschodniej powoduje marginalizację roli Stanów Zjednoczonych w regionie. Podobne obawy może budzić pomysł zacieśniania współpracy politycznej i militarnej. W procesie intensyfikacji, a szczególnie instytucjonalizacji współpracy należy oczekiwać sprzeciwu Stanów Zjednoczonych. Sojusznicza Japonia może sceptycznie podchodzić do finalizowania tych zamierzeń (podobnie Korea Południowa i Australia) ${ }^{23}$.

Na drodze Japonii do supremacji w Azji Wschodniej stoją Chiny, które dokładają starań, aby sprostać wyzwaniom nowoczesnej gospodarki, potrzebom regionu i możliwości odgrywania coraz większej roli w świecie. Mimo że stosunki japońsko-chińskie charakteryzuje współpraca w wielu dziedzinach, nie należy zapominać o istniejących napięciach w stosunkach dwustronnych, dotyczących nierozwiązanych wciąż problemów, będących konsekwencją japońskiej okupacji Chin (kwestia podręcznikowa, sporne wyspy Senkaku-Diaoyutai, japońskie wizyty rządowe w świątyni Yasukuni, a także prawdopodobnie najistotniejsza kwestia stosunków z Tajwanem) ${ }^{24}$. Rozwój stosunków dobrosąsiedzkich, w sytuacji widocznej poprawy koniunktury gospodarczej Chin przekłada się na zmniejszenie wielkości przeznaczanych środków pomocowych z budżetu Japonii. Zmienia się również charakter japońskiej pomocy w kierunku aktywnego partnerstwa, obejmującego kształtowanie stosunków gospodarczych w regionie.

Japonia może odegrać olbrzymią rolę w procesach regionalnej integracji, może również znacznie skorzystać na zacieśnieniu więzów z sąsiadującymi państwami. Uważa się, że dla większości partnerów integracja przyniosłaby szereg wymiernych korzyści (podobnie jak integracja państw w obrębie Unii Europejskiej). Obserwując zmiany i postęp integracji w dziedzinie gospodarki, analizując podobieństwa oraz różnice dotyczące kultur i społeczeństw szeroko pojętej Azji Wschodniej, zwraca się jednak uwagę na przeszkody natury politycznej. Na przyszły sukces czy porażkę może bowiem oddziaływać brak homogeniczności ustrojów politycznych w obrębie regionu, a z perspektywy Japonii, mimo że każdy z rządów będzie zapewniał o potrzebie i gotowości do integracji, pojawiają się obawy i pewnego rodzaju niemoc związana z podejmowaniem decyzji o kluczowym wpływie na tempo i przebieg procesów.

${ }^{23}$ Szerzej na ten temat zob. T. S h ir a is hi, Aiming to Build an East Asian Community, "Japan Echo" 2006, Vol. 33, No. 1, s. 58-63.

${ }^{24}$ Tematykę obszarów spornych pomiędzy Chinami a Japonią wyczerpująco przestawia R. J a k i mow i c z, Stosunki japońsko-chińskie w latach 1949-2002, Wydawnictwo Akademii Ekonomicznej, Kraków 2004, s. 177-211. 
***

Niezbędnym warunkiem powodzenia realizacji zadań, jakie narzucają przeobrażenia współczesnej gospodarki jest rozwój współpracy międzynarodowej. W ramach podejmowanych w tym celu wysiłków Japonia wzmacnia stosunki dwu- oraz wielostronne, m.in. poprzez współpracę gospodarczą i polityczną z państwami regionu Azji Wschodniej oraz uczestnictwo w forach współpracy międzynarodowej. $\mathrm{Z}$ pewnością Japonia chętnie przyjęłaby rolę przewodnią w integracji regionalnej, jednak grono państw zainteresowanych taką pozycją jest coraz większe, co podkreślono podczas ostatniego szczytu państw Azji Wschodniej. Na płaszczyźnie gospodarczej naturalnym kandydatem stają się Chiny oraz Indie. W skład poszerzonego forum mogą wejść inne, równie zamożne, kraje, takie jak Australia i Nowa Zelandia. Jednak one, podobnie jak Japonia, pozostają pod znacznym wpływem Stanów Zjednoczonych. Wielkości przepływu handlu pomiędzy krajami regionu oraz ich zamożność wskazują na niechybną supremację Chin. Silna pozycja ekonomiczna (tempo wzrostu gospodarczego, powiązania handlowe i inwestycyjne wewnątrz regionu) stanowi jednak tylko jedną z przesłanek wyłonienia się kraju wiodącego w regionie. Rola Japonii $\mathrm{w}$ tym procesie wymusza przeprowadzenie znacznych zmian ustawodawstwa państwowego oraz polityki zagranicznej. Szczególnie istotne jest dokonanie zmian w Konstytucji Japonii w części dotyczącej „wyrzeczenia się wojny jako suwerennego prawa narodu" oraz zobowiązania do nieutrzymywania „sił lądowych, morskich i powietrznych” (art. 9) ${ }^{25}$.

${ }^{25}$ Konstytucja Japonii, s. 35. 